Article

\title{
Geochemistry and Petrogenesis of Mesoproterozoic Dykes of the Irkutsk Promontory, Southern Part of the Siberian Craton
}

\author{
T. V. Donskaya ${ }^{1, *}$, D. P. Gladkochub ${ }^{1}{ }^{1}$, R. E. Ernst ${ }^{2,3}{ }^{\circledR}$, S. A. Pisarevsky ${ }^{4}$, A. M. Mazukabzov ${ }^{1}$
} and E. I. Demonterova ${ }^{1}$

1 Institute of the Earth's Crust, Siberian Branch of the Russian Academy of Sciences, ul. Lermontova 128, Irkutsk 664033, Russia; gladkochub@mail.ru (D.P.G.); mazuk@crust.itk.ru (A.M.M.);

dem@crust.irk.ru (E.I.D.)

2 Department of Earth Sciences, Carleton University, Ottawa, ON K1S 5B6, Canada; richard.ernst@ernstgeosciences.com

3 Faculty of Geology and Geography, Tomsk State University, Tomsk 634050, Russia

4 ARC Centre of Excellence for Core to Crust Fluid Systems (CCFS) and Earth Dynamics Research Group, The Institute for Geoscience Research (TIGeR), Department of Applied Geology, Curtin University, GPO Box U1987, Perth, WA 6845, Australia; Sergei.Pisarevskiy@curtin.edu.au

* Correspondence: tatiana_donskaya@mail.ru or tanlen@crust.irk.ru; Tel.: +7-3952-427117

Received: 29 October 2018; Accepted: 20 November 2018; Published: 23 November 2018

\begin{abstract}
We present new geochemical and Nd isotopic data on two Mesoproterozoic Listvyanka $(1350 \pm 6 \mathrm{Ma})$ and Goloustnaya (1338 $\pm 3 \mathrm{Ma})$ mafic dyke swarms located in the Irkutsk Promontory of the southern part of the Siberian craton. Listvyanka dykes are sub-vertical with NNE trend, while Goloustnaya dykes are characterized by prevailing W trend. Listvyanka and Goloustnaya dykes are composed of medium to coarse grained dolerites. All dolerites correspond to sub-alkaline tholeiitic basalts according to their major-element compositions with lower to moderate mg\#, varying from 36 to 54 . The trace and rare earth element abundances in Listvyanka and Goloustnaya dolerites are generally close to basalts of the oceanic island basalts (OIB) type. The Listvyanka dolerites demonstrate slightly positive $\varepsilon \mathrm{Nd}(\mathrm{t})$ values varying from +1.1 to +1.5 , while the Goloustnaya dolerites are characterized by lower $\varepsilon \mathrm{Nd}(\mathrm{t})$ values ranging from -0.9 to +0.1 . Geochemical and isotopic affinities of the Listvyanka dolerites suggest their enrichment by a mantle plume related source. For the Goloustnaya dolerites, we assume also some additional lithospheric input to their mantle plume-related source. The emplacement of both studied dolerites took place in intracontinental extensional setting, caused by a single rising mantle plume. Listvyanka and Goloustnaya dolerites are coeval to several mafic magmatic events in northern Laurentia and likely represent part of the Mesoproterozoic plumbing system of a Siberian-Laurentian Large Igneous Province.
\end{abstract}

Keywords: dolerites; dykes; geochemistry; Nd isotopes; Mesoproterozoic; Siberian craton

\section{Introduction}

The time period of 1.70-0.75 Ga is often described as the Super Gap [1,2], Boring Billion [3] or Earth's Middle Age [4]. Cawood and Hawkesworth [4] showed that during this period there were no global glaciations, no orogenic gold, no volcanic-hosted massive sulfide deposits, no major iron formations and just a few preserved passive margin sequences. At the same time, anorthosite complexes and Large Igneous Provinces (LIPs) were abundant in this time period. The close proximity of southern Siberia and northern Laurentia (cratonic part of North America) during this time is postulated in recent paleogeographic reconstructions, e.g., [5-7]. Alternative Siberia vs. Laurentia 
reconstruction with northern Siberia attached to western Laurentia [8-10], or with northern Siberia attached to northern Laurentia [11,12] have been analyzed and found to: (i) contradict Mesoproterozoic paleomagnetic data from both continents, e.g., [13-17]; (ii) be mostly inconsistent with LIPs records in both continents, e.g., [7,18]; (iii) contain more geological mismatches than matches, e.g., [13]. Additionally, the connection between northern Siberia and western Laurentia is inconsistent with many geological and paleomagnetic lines of evidence of the connection between Australia-Antarctica with western Laurentia in Mesoproterozoic, e.g., [16,19-23]. It is also suggested that Siberia and Laurentia were parts of the Mesoproterozoic supercontinent Columbia (aka Nuna), formed between 1.8 and 1.6 Ga and partially disintegrated between 1.4 and $1.2 \mathrm{Ga}$, e.g., [19,24], and of the Neoproterozoic supercontinent Rodinia, formed between 1.1 and $0.9 \mathrm{Ga}$ and broken apart after 0.8 Ga, e.g., [14]. However, although Mesoproterozoic LIP-related magmatic rocks are widely spread in northern Laurentia, e.g., [4,7], their occurrences are limited in the southern part of the Siberian craton. Gladkochub et al. [2,18] suggested the almost complete absence of Mesoproterozoic magmatism in the southern part of the Siberian craton, but this conclusion was based mainly on the absence of reliable age determinations at that time.

In 2016, Ernst et al. [7] reported the ages of two Mesoproterozoic intrusions in the southern part of the Siberian craton: $1350 \pm 6$ Ma Listvyanka dyke and $1258 \pm 5$ Ma Srednecheremshanskaya dyke. The former is nearly coeval to the $1353 \pm 2$ Ma Barking Dog gabbro sill in northern Laurentia and may represent the same large igneous event. The latter is slightly younger that the huge 1267-1270 Ma Laurentian Mackenzie LIP. These findings potentially provide Mesoproterozoic piercing points between southern Siberia and northern Laurentia. Recently Gladkochub et al. [25] reported the $1338 \pm 3 \mathrm{Ma}$ age for another dyke swarm (Goloustnaya) in the southern part of the Siberian craton, but the nature of these dykes is still unclear.

Here we present the geochemical and isotopic characteristics of Listvyanka and Goloustnaya swarms and discuss their origin and geodynamic interpretations.

\section{Geological Setting}

The Siberian craton was assembled in Paleoproterozoic by amalgamation of Archean and Paleoproterozoic terranes (building blocks), e.g., [26-28]. Building blocks of the craton are welded by $\sim 1.8-2.0 \mathrm{Ga}$ orogenic belts and suture zones [26-29]. The southern part of the craton (Irkutsk Promontory) is subdivided into Archean Tungus and Magan terranes and Paleoproterozoic Akitkan fold belt (Figure 1). In Irkutsk Promontory, the basement rocks of Tungus terrane and Akitkan fold belt are exposed in the Sharyzhalgai and Baikal inliers, respectively. The basement rocks of Magan terrane are completely covered by Phanerozoic sedimentary rocks.

Mesoproterozoic dykes in the Irkutsk Promontory are exposed along the coast of Lake Baikal near the village of Listvyanka (Sharyzhalgai inlier) and in the Goloustnaya area (Baikal inlier) (Figure 1).

The Listvyanka dykes include one relatively thick dyke $(30 \mathrm{~m})$ and several smaller dykes (Figure 3). They intrude Archean and Paleoproterozoic metamorphic and igneous rocks of the Sharyzhalgai inlier. The dykes are sub-vertical with a NNE trend (10-20).

The Listvyanka dykes are composed of medium- to coarse-grained dolerite. They consist of rock-forming plagioclase and clinopyroxene, minor amphibole, biotite, quartz and ore minerals, as well as accessory apatite, titanate, zircon and baddeleyite (Figure 2a). The rocks were altered by oxidation, saussuritization, albitization and sometimes carbonatization. Pyroxene and biotite are partly replaced by amphibole and chlorite, respectively. The $\mathrm{U}-\mathrm{Pb}$ baddeleyite and zircon age of the thick dyke is $1350 \pm 6 \mathrm{Ma}$ [7]. 


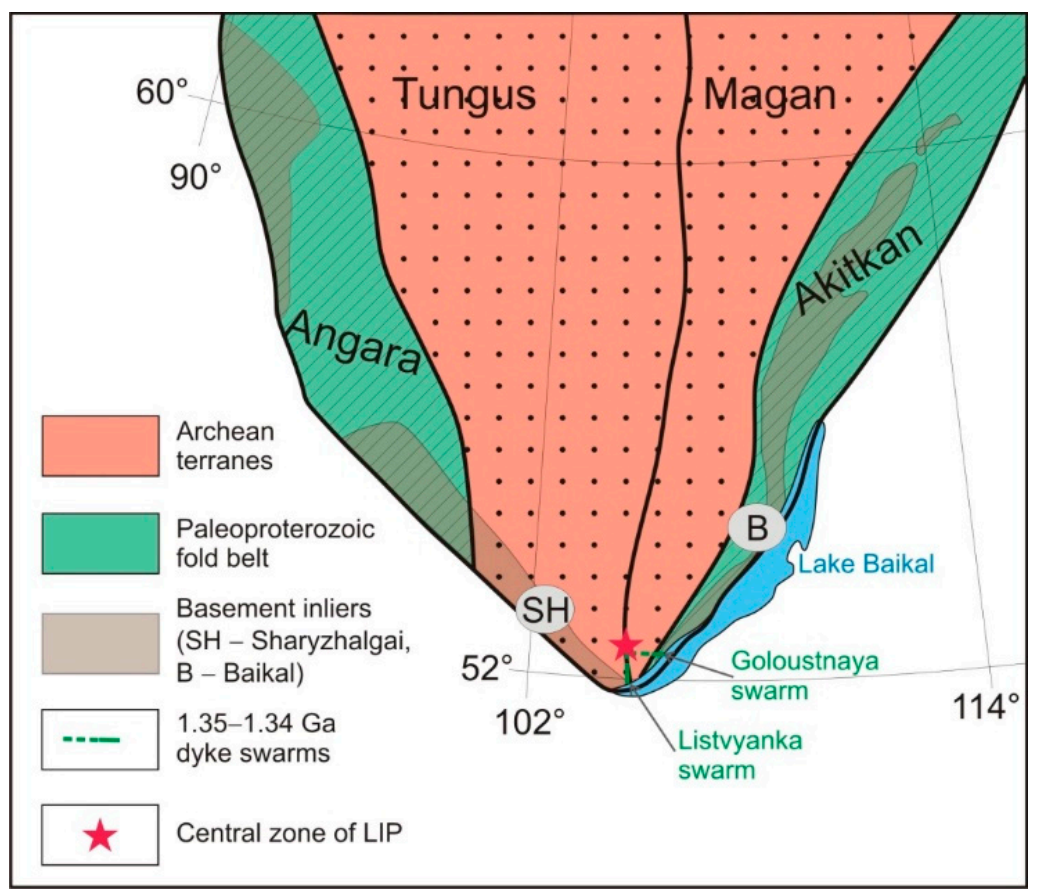

Figure 1. Major tectonic elements of the Irkutsk Promontory of the southern part of the Siberian craton (modified after [26-28]).
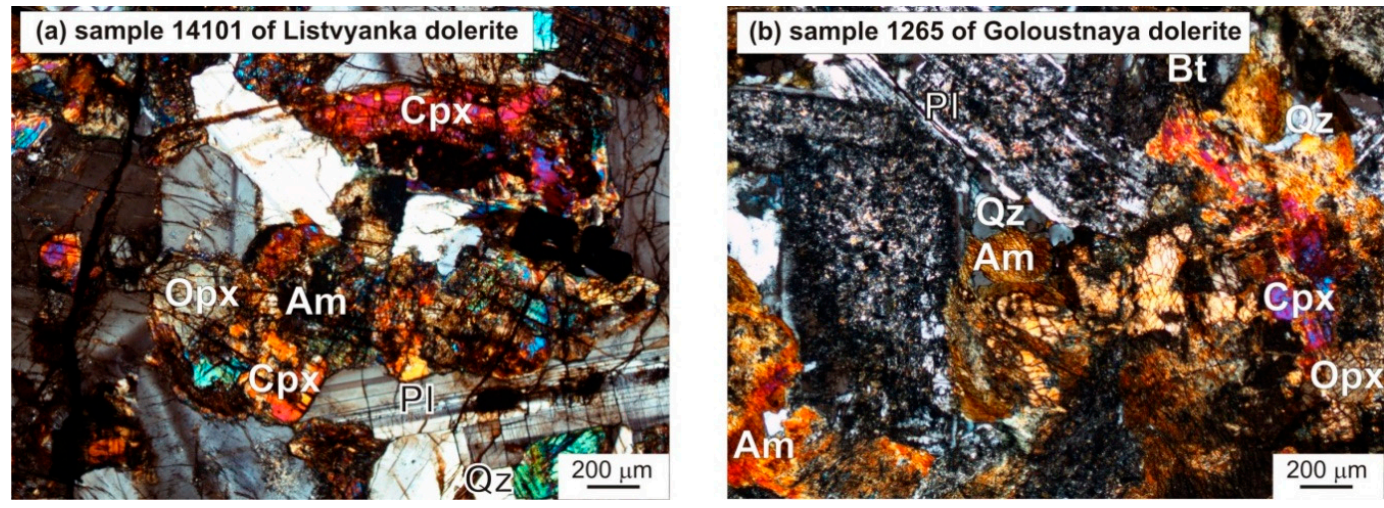

Figure 2. Photomicrographs of Listvyanka and Goloustnaya dolerites: (a) sample 14101 of Listvyanka dolerite and (b) sample 1265 of Goloustnaya dolerite. Mineral abbreviations: Amp, amphibole; Cpx, clinopyroxene; Opx, orthopyroxene; $\mathrm{Pl}$, plagioclase; $\mathrm{Bt}$, biotite; Qz, quartz.

A series of dykes and dyke-like intrusions were found along the south-eastern shore of Lake Baikal north of the Bolshaya Goloustnaya village (the Goloustnaya area). These dykes cut mainly Paleoproterozoic migmatites, granite gneisses, and granites of the Goloustnaya block of the Baikal inlier (Figure 4). The contact of these dykes with host-rocks is sharp and clear, but sometimes they have a curved configuration. The dykes are sub-vertical with a prevailing $\mathrm{W}$ trend. Thicknesses of these dykes vary from two meters to one hundred meters. Dykes are composed of medium and coarse-grained dolerite. Rock-forming minerals are clinopyroxene and plagioclase (Figure 2b). Less abundant are orthopyroxenes, amphibole, biotite, quartz, ore minerals and sometimes K-feldspar. Apatite, titanite, rutile, zircon and baddeleyite are typical accessory minerals. Some dolerites underwent low-temperature alteration, which caused partial saussuritization of plagioclase, clinopyroxene replacement by amphibole, and biotite replacement by chlorite, as well as formation of secondary epidote, quartz, hydrous ferric oxides, albite and calcite. The U-Pb baddeleyite and zircon age of dolerite is $1338.5 \pm 6.9 \mathrm{Ma}$ and the weighted mean ${ }^{207} \mathrm{~Pb} /{ }^{206} \mathrm{~Pb}$ zircon age is $1338.0 \pm 2.9 \mathrm{Ma}$ [25]. 
Table 1. Geochemical compositions of the Listvyanka and Goloustnaya dolerites.

\begin{tabular}{|c|c|c|c|c|c|c|c|c|c|c|c|c|}
\hline \multirow{3}{*}{$\begin{array}{c}\text { Location } \\
\text { Dyke Number } \\
\text { Sample }\end{array}$} & \multicolumn{5}{|c|}{ Listvyanka } & \multicolumn{7}{|c|}{ Goloustnaya } \\
\hline & \multicolumn{4}{|c|}{1} & 2 & \multicolumn{2}{|c|}{3} & \multicolumn{5}{|c|}{4} \\
\hline & 1283 & $1283 a$ & 14101 & 14102 & 14103 & 1261 & 1401 & 1263 & 1264 & 1265 & 1402 & 1403 \\
\hline $\mathrm{SiO}_{2}$, wt. $\%$ & 48.57 & 48.23 & 49.28 & 47.71 & 47.52 & 48.60 & 47.30 & 49.46 & 48.88 & 50.36 & 47.37 & 46.72 \\
\hline $\mathrm{TiO}_{2}$ & 2.24 & 2.58 & 1.64 & 2.29 & 2.34 & 2.75 & 2.75 & 2.32 & 2.08 & 2.00 & 2.67 & 2.75 \\
\hline $\mathrm{Al}_{2} \mathrm{O}_{3}$ & 13.55 & 12.60 & 14.75 & 13.20 & 13.75 & 12.84 & 13.05 & 12.72 & 14.46 & 14.28 & 13.40 & 13.50 \\
\hline $\mathrm{Fe}_{2} \mathrm{O}_{3}$ & 3.31 & 3.21 & 3.13 & 3.45 & 3.66 & 3.42 & 4.08 & 1.76 & 2.94 & 2.31 & 3.61 & 3.50 \\
\hline $\mathrm{FeO}$ & 10.19 & 11.37 & 8.53 & 10.89 & 11.12 & 10.78 & 10.68 & 11.82 & 9.92 & 9.56 & 11.03 & 10.76 \\
\hline $\mathrm{MnO}$ & 0.21 & 0.23 & 0.17 & 0.22 & 0.24 & 0.19 & 0.20 & 0.22 & 0.18 & 0.18 & 0.20 & 0.19 \\
\hline $\mathrm{MgO}$ & 5.91 & 6.71 & 6.24 & 6.67 & 6.25 & 5.99 & 5.94 & 6.13 & 5.54 & 5.35 & 6.18 & 6.53 \\
\hline $\mathrm{CaO}$ & 9.48 & 9.72 & 10.48 & 9.35 & 8.52 & 8.93 & 9.53 & 7.79 & 8.72 & 8.63 & 9.27 & 9.53 \\
\hline $\mathrm{Na}_{2} \mathrm{O}$ & 2.71 & 2.50 & 2.48 & 2.73 & 2.26 & 2.18 & 1.86 & 2.72 & 2.40 & 2.52 & 2.74 & 2.31 \\
\hline $\mathrm{K}_{2} \mathrm{O}$ & 0.5 & 0.31 & 0.39 & 0.66 & 1.26 & 0.87 & 1.15 & 0.82 & 0.83 & 0.78 & 0.62 & 0.66 \\
\hline $\mathrm{P}_{2} \mathrm{O}_{5}$ & 0.28 & 0.28 & 0.19 & 0.31 & 0.26 & 0.37 & 0.38 & 0.44 & 0.36 & 0.46 & 0.27 & 0.31 \\
\hline LOI & 2.19 & 2.29 & 1.68 & 2.03 & 2.83 & 2.91 & 3.10 & 3.33 & 3.04 & 3.04 & 2.86 & 3.28 \\
\hline $\mathrm{H}_{2} \mathrm{O}^{-}$ & 0.14 & 0.09 & 0.19 & 0.12 & 0.13 & 0.24 & 0.14 & 0.28 & 0.31 & 0.22 & 0.11 & 0.11 \\
\hline $\mathrm{CO}_{2}$ & 0.69 & 0.23 & 0.54 & 0.24 & 0.11 & $<0.06$ & - & 0.09 & 0.09 & 0.09 & - & 0.28 \\
\hline Total & 99.97 & 100.35 & 99.69 & 99.87 & 100.25 & 100.06 & 100.16 & 99.90 & 99.74 & 99.78 & 100.33 & 100.43 \\
\hline $\mathrm{Rb}, \mathrm{ppm}$ & 15 & 7 & 8 & 22 & 32 & 26 & 64 & 26 & 20 & 20 & 25 & 21 \\
\hline $\mathrm{Sr}$ & 361 & 335 & 324 & 350 & 270 & 227 & 242 & 225 & 255 & 267 & 230 & 194 \\
\hline$Y$ & 25 & 24 & 16 & 24 & 20 & 34 & 36 & 38 & 34 & 39 & 28 & 30 \\
\hline $\mathrm{Zr}$ & 170 & 149 & 97 & 150 & 124 & 212 & 218 & 247 & 221 & 254 & 159 & 184 \\
\hline $\mathrm{Nb}$ & 25 & 25 & 24 & 24 & 21 & 24 & 25 & 30 & 24 & 28 & 17 & 20 \\
\hline $\mathrm{Ba}$ & 150 & 74 & 113 & 154 & 333 & 283 & 293 & 315 & 335 & 390 & 242 & 233 \\
\hline $\mathrm{La}$ & 21.13 & 19.96 & 13.92 & 21.65 & 18.04 & 24.81 & 29.96 & 30.69 & 24.31 & 29.54 & 19.29 & 22.70 \\
\hline $\mathrm{Ce}$ & 45.56 & 43.06 & 29.79 & 48.03 & 38.16 & 55.46 & 65.76 & 67.65 & 55.33 & 67.01 & 43.44 & 50.67 \\
\hline $\operatorname{Pr}$ & 6.10 & 5.93 & 3.86 & 6.13 & 4.90 & 7.25 & 8.11 & 8.63 & 7.23 & 8.63 & 5.46 & 6.27 \\
\hline $\mathrm{Nd}$ & 24.86 & 24.26 & 16.07 & 26.39 & 21.33 & 29.37 & 33.41 & 36.07 & 30.52 & 36.62 & 23.12 & 25.98 \\
\hline $\mathrm{Sm}$ & 5.62 & 5.62 & 3.91 & 5.93 & 4.79 & 7.15 & 8.22 & 8.51 & 6.92 & 8.47 & 5.36 & 6.57 \\
\hline $\mathrm{Eu}$ & 1.90 & 1.78 & 1.26 & 1.80 & 1.52 & 2.03 & 2.32 & 2.31 & 2.10 & 2.49 & 1.74 & 2.05 \\
\hline $\mathrm{Gd}$ & 5.02 & 4.93 & 3.27 & 4.90 & 4.00 & 5.77 & 7.06 & 6.76 & 5.68 & 7.05 & 5.12 & 5.78 \\
\hline $\mathrm{Tb}$ & 0.76 & 0.75 & 0.50 & 0.74 & 0.59 & 0.95 & 1.11 & 1.10 & 0.95 & 1.16 & 0.83 & 0.91 \\
\hline Dy & 4.69 & 4.53 & 2.97 & 4.56 & 3.61 & 5.96 & 6.46 & 6.73 & 5.95 & 6.98 & 5.08 & 5.32 \\
\hline Ho & 0.90 & 0.88 & 0.59 & 0.92 & 0.74 & 1.24 & 1.28 & 1.40 & 1.22 & 1.40 & 1.00 & 1.08 \\
\hline $\mathrm{Er}$ & 2.42 & 2.22 & 1.66 & 2.48 & 1.98 & 3.09 & 3.21 & 3.48 & 3.16 & 3.58 & 2.65 & 2.81 \\
\hline
\end{tabular}


Table 1. Cont.

\begin{tabular}{|c|c|c|c|c|c|c|c|c|c|c|c|c|}
\hline $\mathrm{Tm}$ & 0.37 & 0.32 & 0.22 & 0.35 & 0.28 & 0.45 & 0.48 & 0.51 & 0.48 & 0.53 & 0.39 & 0.42 \\
\hline $\mathrm{Yb}$ & 2.26 & 2.04 & 1.34 & 2.11 & 1.74 & 2.75 & 2.90 & 3.14 & 2.84 & 3.25 & 2.31 & 2.38 \\
\hline $\mathrm{Lu}$ & 0.33 & 0.31 & 0.22 & 0.32 & 0.29 & 0.42 & 0.45 & 0.50 & 0.45 & 0.50 & 0.34 & 0.36 \\
\hline Hf & 4.08 & 3.61 & 2.66 & 3.90 & 3.30 & 5.04 & 5.33 & 5.97 & 5.29 & 6.10 & 4.08 & 4.65 \\
\hline Ta & 1.65 & 1.42 & 2.47 & 1.53 & 1.35 & 1.44 & 1.53 & 1.78 & 1.42 & 1.72 & 0.78 & 1.28 \\
\hline Th & 1.90 & 1.54 & 1.34 & 2.03 & 1.71 & 1.78 & 2.60 & 2.53 & 1.95 & 2.45 & 1.61 & 1.82 \\
\hline $\mathrm{U}$ & 0.50 & 0.34 & 0.33 & 0.41 & 0.34 & 0.94 & 0.97 & 0.63 & 0.69 & 0.72 & 0.41 & 0.43 \\
\hline mg\# & 48 & 50 & 54 & 50 & 48 & 48 & 46 & 49 & 48 & 49 & 48 & 50 \\
\hline$(\mathrm{La} / \mathrm{Yb})_{\mathrm{n}}$ & 6.06 & 6.32 & 6.70 & 6.65 & 6.70 & 5.84 & 6.68 & 6.31 & 5.54 & 5.89 & 5.40 & 6.16 \\
\hline $\mathrm{Eu} / \mathrm{Eu}^{*}$ & 1.10 & 1.05 & 1.08 & 1.03 & 1.07 & 0.97 & 0.94 & 0.94 & 1.03 & 0.99 & 1.03 & 1.02 \\
\hline $\mathrm{Nb} / \mathrm{Nb}^{*}$ & 1.36 & 1.51 & 1.89 & 1.25 & 1.26 & 1.22 & 0.95 & 1.17 & 1.19 & 1.13 & 0.77 & 0.95 \\
\hline $\mathrm{Ti} / \mathrm{Ti}^{*}$ & 0.99 & 1.15 & 1.08 & 1.00 & 1.26 & 1.01 & 0.85 & 0.72 & 0.78 & 0.61 & 1.20 & 1.05 \\
\hline Location & \multicolumn{12}{|c|}{ Goloustnaya } \\
\hline Dyke Number & 4 & \multicolumn{2}{|c|}{5} & \multicolumn{2}{|c|}{6} & \multicolumn{4}{|c|}{7} & 8 & \multicolumn{2}{|c|}{9} \\
\hline Sample & 1404 & 1266 & 1267 & 1412 & 1414 & 1278 & 1279 & 1425 & 1428 & 1435 & 1437 & 1438 \\
\hline $\mathrm{SiO}_{2}$, wt. $\%$ & 49.31 & 49.02 & 46.96 & 47.66 & 50.21 & 49.25 & 49.42 & 48.48 & 47.69 & 48.33 & 48.77 & 47.94 \\
\hline $\mathrm{TiO}_{2}$ & 2.95 & 2.57 & 3.18 & 2.77 & 2.43 & 2.91 & 2.95 & 2.62 & 2.88 & 2.58 & 2.33 & 3.31 \\
\hline $\mathrm{Al}_{2} \mathrm{O}_{3}$ & 13.65 & 15.37 & 11.85 & 13.60 & 15.80 & 13.70 & 13.30 & 14.30 & 13.78 & 14.32 & 13.04 & 13.57 \\
\hline $\mathrm{Fe}_{2} \mathrm{O}_{3}$ & 3.80 & 2.90 & 4.20 & 4.02 & 3.43 & 4.28 & 4.40 & 4.25 & 4.05 & 4.34 & 4.62 & 4.61 \\
\hline $\mathrm{FeO}$ & 10.64 & 9.28 & 11.52 & 10.72 & 8.82 & 10.72 & 10.68 & 9.53 & 10.04 & 9.85 & 8.84 & 11.23 \\
\hline $\mathrm{MnO}$ & 0.18 & 0.17 & 0.16 & 0.18 & 0.15 & 0.19 & 0.19 & 0.18 & 0.19 & 0.18 & 0.16 & 0.20 \\
\hline $\mathrm{MgO}$ & 4.18 & 4.24 & 5.53 & 5.60 & 3.91 & 3.95 & 3.95 & 5.16 & 6.18 & 5.24 & 6.08 & 4.09 \\
\hline $\mathrm{CaO}$ & 8.14 & 8.29 & 7.43 & 9.00 & 8.27 & 8.21 & 8.13 & 9.63 & 9.75 & 8.80 & 8.84 & 7.96 \\
\hline $\mathrm{Na}_{2} \mathrm{O}$ & 3.02 & 2.63 & 1.65 & 2.43 & 3.08 & 2.41 & 2.72 & 2.53 & 2.19 & 2.33 & 2.21 & 2.37 \\
\hline $\mathrm{K}_{2} \mathrm{O}$ & 0.81 & 0.79 & 0.56 & 0.90 & 0.72 & 1.19 & 1.2 & 0.69 & 0.6 & 0.81 & 1.48 & 1.07 \\
\hline $\mathrm{P}_{2} \mathrm{O}_{5}$ & 0.74 & 0.42 & 0.41 & 0.34 & 0.44 & 0.65 & 0.57 & 0.33 & 0.26 & 0.32 & 0.24 & 0.66 \\
\hline LOI & 2.84 & 3.37 & 4.02 & 2.72 & 3.00 & 2.74 & 2.48 & 2.06 & 2.21 & 2.26 & 2.69 & 2.67 \\
\hline $\mathrm{H}_{2} \mathrm{O}^{-}$ & 0.12 & 0.30 & 0.29 & 0.19 & 0.14 & 0.16 & 0.13 & 0.13 & 0.20 & 0.08 & 0.17 & 0.06 \\
\hline $\mathrm{CO}_{2}$ & - & 0.56 & 1.94 & 0.24 & $<0.06$ & $<0.06$ & 0.17 & 0.41 & 0.15 & 0.36 & 0.31 & 0.22 \\
\hline Total & 100.38 & 99.91 & 99.70 & 100.37 & 100.40 & 100.36 & 100.29 & 100.30 & 100.17 & 99.80 & 99.78 & 99.96 \\
\hline $\mathrm{Rb}, \mathrm{ppm}$ & 26 & 30 & 23 & 24 & 26 & 31 & 30 & 22 & 19 & 26 & 65 & 28 \\
\hline $\mathrm{Sr}$ & 290 & 269 & 144 & 236 & 391 & 242 & 262 & 276 & 254 & 259 & 254 & 256 \\
\hline $\mathrm{Y}$ & 45 & 34 & 35 & 33 & 41 & 45 & 43 & 32 & 27 & 31 & 24 & 42 \\
\hline $\mathrm{Zr}$ & 302 & 234 & 233 & 222 & 294 & 305 & 291 & 208 & 166 & 190 & 146 & 268 \\
\hline $\mathrm{Nb}$ & 33 & 25 & 29 & 26 & 29 & 33 & 33 & 22 & 17 & 20 & 15 & 32 \\
\hline $\mathrm{Ba}$ & 459 & 341 & 166 & 384 & 356 & 488 & 450 & 298 & 259 & 436 & 426 & 463 \\
\hline
\end{tabular}


Table 1. Cont.

\begin{tabular}{|c|c|c|c|c|c|c|c|c|c|c|c|c|}
\hline $\mathrm{La}$ & 37.81 & 27.10 & 25.46 & 26.62 & 35.16 & 35.97 & 33.55 & 24.27 & 19.99 & 22.22 & 17.30 & 34.43 \\
\hline $\mathrm{Ce}$ & 85.88 & 61.49 & 58.28 & 61.05 & 79.08 & 82.94 & 77.53 & 56.00 & 45.91 & 50.66 & 39.10 & 78.99 \\
\hline $\operatorname{Pr}$ & 10.60 & 7.92 & 7.69 & 7.48 & 9.62 & 10.68 & 9.97 & 6.78 & 5.71 & 6.29 & 4.96 & 9.81 \\
\hline $\mathrm{Nd}$ & 43.75 & 32.92 & 31.72 & 30.24 & 39.07 & 44.48 & 42.18 & 28.16 & 23.83 & 26.80 & 20.68 & 40.90 \\
\hline $\mathrm{Sm}$ & 10.36 & 7.51 & 7.92 & 7.50 & 9.38 & 10.30 & 9.40 & 6.86 & 6.15 & 6.59 & 5.14 & 10.13 \\
\hline $\mathrm{Eu}$ & 3.16 & 2.24 & 2.13 & 2.33 & 2.82 & 2.91 & 2.78 & 2.09 & 1.87 & 2.06 & 1.59 & 2.95 \\
\hline $\mathrm{Gd}$ & 9.01 & 6.61 & 6.38 & 6.36 & 8.03 & 8.32 & 7.91 & 6.10 & 5.10 & 5.84 & 4.68 & 8.75 \\
\hline $\mathrm{Tb}$ & 1.33 & 1.04 & 1.05 & 1.02 & 1.31 & 1.32 & 1.28 & 0.99 & 0.85 & 0.96 & 0.75 & 1.35 \\
\hline Dy & 8.18 & 6.20 & 6.30 & 6.08 & 7.61 & 8.03 & 7.59 & 5.78 & 5.00 & 5.66 & 4.52 & 7.89 \\
\hline Ho & 1.63 & 1.27 & 1.26 & 1.22 & 1.53 & 1.66 & 1.57 & 1.17 & 1.02 & 1.06 & 0.89 & 1.58 \\
\hline $\mathrm{Er}$ & 4.17 & 3.13 & 3.30 & 3.20 & 3.85 & 4.18 & 3.94 & 3.04 & 2.52 & 2.87 & 2.47 & 4.00 \\
\hline $\mathrm{Tm}$ & 0.61 & 0.45 & 0.49 & 0.48 & 0.56 & 0.60 & 0.57 & 0.42 & 0.38 & 0.43 & 0.35 & 0.57 \\
\hline $\mathrm{Yb}$ & 3.74 & 2.83 & 3.06 & 2.85 & 3.43 & 3.64 & 3.44 & 2.71 & 2.27 & 2.63 & 2.10 & 3.46 \\
\hline $\mathrm{Lu}$ & 0.53 & 0.44 & 0.48 & 0.44 & 0.54 & 0.55 & 0.54 & 0.40 & 0.35 & 0.39 & 0.31 & 0.51 \\
\hline $\mathrm{Hf}$ & 7.62 & 5.46 & 5.58 & 5.48 & 7.13 & 7.36 & 6.81 & 5.27 & 4.11 & 4.95 & 3.55 & 6.74 \\
\hline Ta & 2.12 & 1.55 & 1.73 & 1.60 & 1.84 & 2.04 & 2.01 & 1.44 & 0.78 & 1.29 & 1.00 & 2.12 \\
\hline Th & 3.42 & 2.28 & 2.08 & 2.40 & 3.24 & 3.03 & 2.89 & 2.16 & 1.60 & 1.84 & 1.46 & 2.88 \\
\hline $\mathrm{U}$ & 0.80 & 0.83 & 0.98 & 0.57 & 0.80 & 0.74 & 0.67 & 0.51 & 0.41 & 0.51 & 0.49 & 0.96 \\
\hline mg\# & 38 & 43 & 43 & 45 & 41 & 36 & 36 & 45 & 49 & 44 & 50 & 36 \\
\hline$(\mathrm{La} / \mathrm{Yb})_{\mathrm{n}}$ & 6.54 & 6.20 & 5.38 & 6.05 & 6.64 & 6.40 & 6.32 & 5.79 & 5.69 & 5.47 & 5.33 & 6.43 \\
\hline $\mathrm{Eu} / \mathrm{Eu}^{*}$ & 1.01 & 0.98 & 0.92 & 1.04 & 1.00 & 0.97 & 0.99 & 1.00 & 1.03 & 1.02 & 1.00 & 0.97 \\
\hline $\mathrm{Nb} / \mathrm{Nb}^{*}$ & 1.17 & 1.10 & 1.36 & 0.87 & 0.91 & 1.07 & 1.15 & 1.02 & 0.81 & 1.01 & 0.68 & 1.07 \\
\hline $\mathrm{Ti} / \mathrm{Ti}^{*}$ & 0.72 & 0.86 & 1.05 & 0.94 & 0.66 & 0.74 & 0.80 & 0.95 & 1.21 & 0.98 & 1.12 & 0.83 \\
\hline
\end{tabular}

$\mathrm{mg} \#=\mathrm{Mg} \times 100 /\left(\mathrm{Mg}+\mathrm{Fe}^{2+}\right)$, where $\mathrm{Mg}=\mathrm{MgO} / 40.31, \mathrm{Fe}^{2+}=\left(\mathrm{Fe}_{2} \mathrm{O}_{3}{ }^{*} \times 0.8998 \times 0.85\right) / 71.85 ; \mathrm{Eu} / \mathrm{Eu}^{*}=\mathrm{Eu}_{\mathrm{n}} /\left(\sqrt{ }\left(\mathrm{Sm}_{\mathrm{n}} \times \mathrm{Gd}_{\mathrm{n}}\right)\right) ; \mathrm{Nb} / \mathrm{Nb}^{*}=\mathrm{Nb}_{\mathrm{pm}} /\left(\sqrt{ }\left(\mathrm{Th}_{\mathrm{pm}} \times \mathrm{La}_{\mathrm{pm}}\right)\right) ; \mathrm{Ti} / \mathrm{Ti}^{*}=$ $\mathrm{Ti}_{\mathrm{pm}} /\left(\sqrt{ }\left(\mathrm{Sm}_{\mathrm{pm}} \times \mathrm{Gd}_{\mathrm{pm}}\right)\right) ; \mathrm{n}$, chondrite-normalized elements; $\mathrm{pm}$, primitive mantle-normalized elements. 


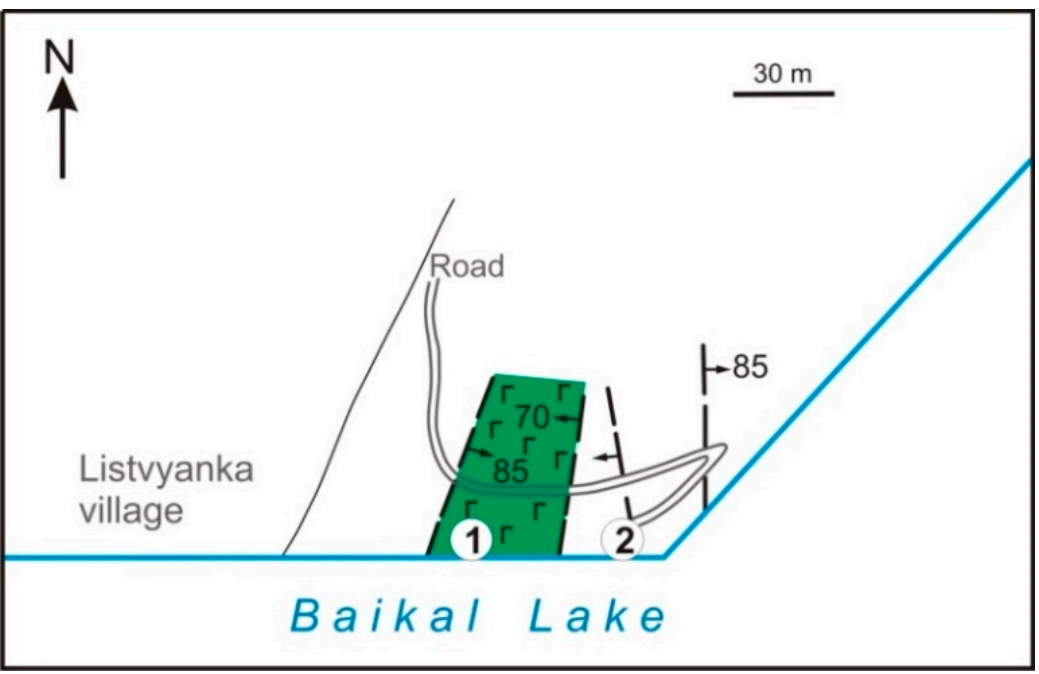

Figure 3. Sketch map showing the location of several dykes of the Listvyanka swarm along the western short of Lake Baikal (modified after [7]). The numbers of dykes according to Table 1 are shown in circles.

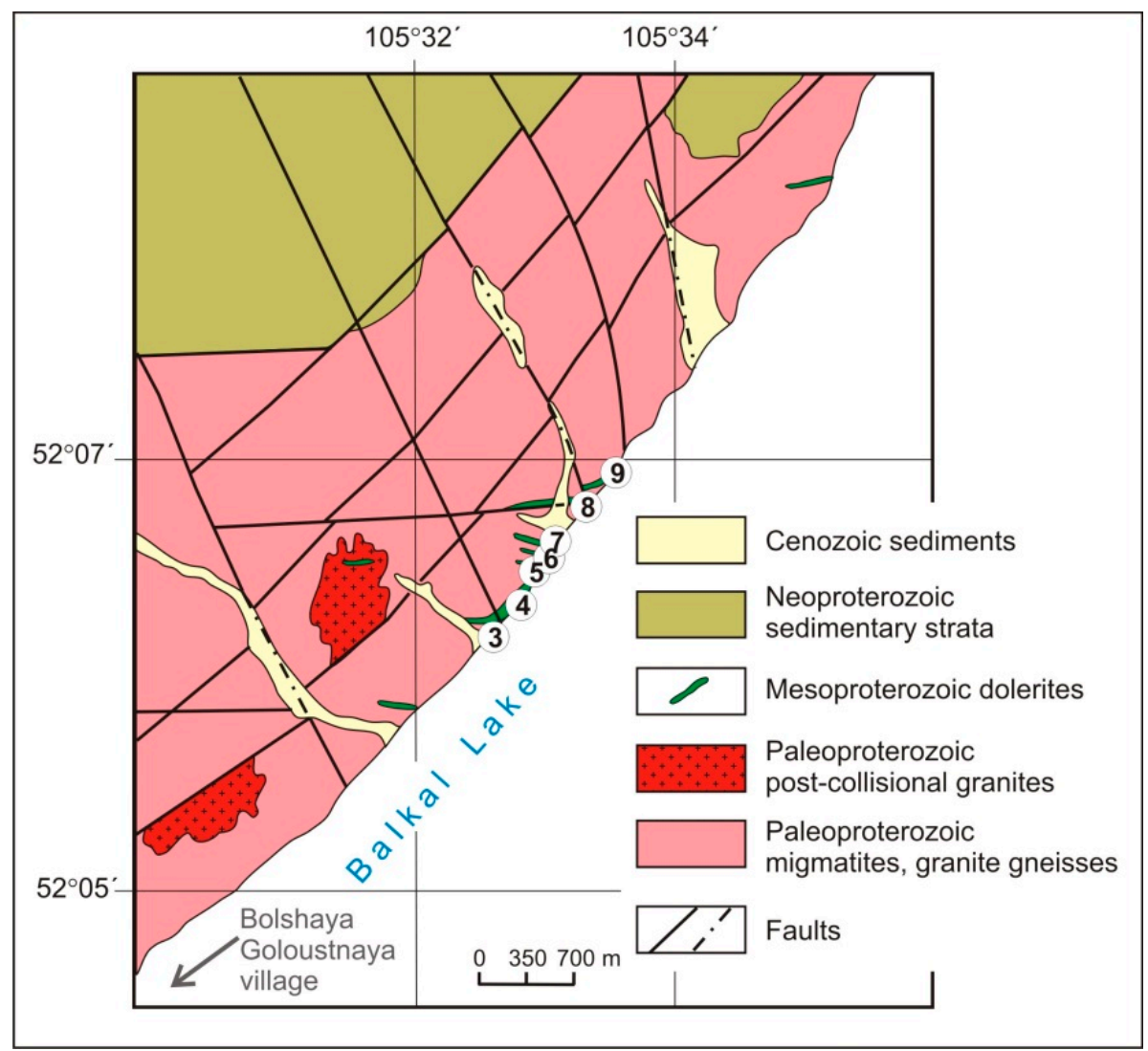

Figure 4. Geological scheme of the Goloustnaya area, showing the locations of dykes of Goloustnaya swarm (modified after [25]). The numbers of dykes according to Table 1 are shown in circles.

\section{Methods}

Five samples from two Listvyanka dykes and 19 samples from five Goloustnaya dykes were collected for analysis of major-oxide, trace-element, REE abundances, and $\mathrm{Nd}$ isotope systematics. Analytical data are summarized in Tables 1 and 2. 
Table 2. Sm-Nd isotopic data for the Listvyanka and Goloustnaya dolerites.

\begin{tabular}{|c|c|c|c|c|c|c|c|}
\hline \multirow{2}{*}{ Sample } & \multirow{2}{*}{$\mathrm{T}, \mathrm{Ma}$} & \multirow{2}{*}{$\begin{array}{c}\text { Sm } \\
(\mathrm{ppm})\end{array}$} & \multirow{2}{*}{ Nd (ppm) } & ${ }^{147} \mathrm{Sm} /{ }^{144} \mathrm{Nd}$ & ${ }^{143} \mathrm{Nd} /{ }^{144} \mathrm{Nd}$ & $\varepsilon_{N d}(t)$ & $\mathrm{T}_{\mathrm{Nd}}(\mathrm{DM})$ \\
\hline & & & & \multicolumn{3}{|c|}{ $\pm 2 \sigma$} & Ma \\
\hline \multicolumn{8}{|c|}{ Listvyanka dolerites } \\
\hline 1283 & 1350 & 4.50 & 18.35 & 0.1325 & $0.512146 \pm 10$ & 1.5 & 1882 \\
\hline 14101 & 1350 & 2.97 & 11.65 & 0.1374 & $0.512175 \pm 10$ & 1.2 & 1947 \\
\hline 14103 & 1350 & 4.06 & 16.46 & 0.1330 & $0.512129 \pm 11$ & 1.1 & 1926 \\
\hline \multicolumn{8}{|c|}{ Goloustnaya dolerites } \\
\hline 1265 & 1338 & 5.23 & 21.10 & 0.1339 & $0.512060 \pm 11$ & -0.5 & 2079 \\
\hline 1267 & 1338 & 6.22 & 24.98 & 0.1345 & $0.512078 \pm 11$ & -0.2 & 2059 \\
\hline 1279 & 1338 & 6.32 & 25.91 & 0.1316 & $0.512021 \pm 10$ & -0.9 & 2094 \\
\hline 1401 & 1338 & 4.00 & 15.33 & 0.1407 & $0.512152 \pm 10$ & 0.1 & 2080 \\
\hline 1428 & 1338 & 3.33 & 12.46 & 0.1444 & $0.512140 \pm 10$ & -0.7 & 2217 \\
\hline
\end{tabular}

Major elements were analysed by wet chemistry at the Centre for Geodynamics and Geochronology of the Institute of the Earth's Crust SB RAS (Irkutsk, Russia). Trace elements and rare earths were determined by inductively coupled plasma mass spectrometry (ICP-MS) on an Agilent Technologies Agilent 7500ce analyzer at the Limnological Institute SB RAS (Irkutsk, Russia). For ICP-MS, the samples were fused with $\mathrm{LiBO}_{2}$ following the procedure of Panteeva et al. [30]. Calibrations were with internal and international standards G-2, GSP-2, JG-2, and RGM-1. Analytical accuracy was $0.5-1.0 \%$ for major oxides and up to $5 \%$ for trace elements and REE.

$\mathrm{Sm}-\mathrm{Nd}$ isotopic analyses were made at the Centre for Geodynamics and Geochronology of the Institute of the Earth's Crust SB RAS (Irkutsk, Russia). Details of the analytical procedures are described by Vanin et al. [31]. Isotopic compositions of $\mathrm{Nd}$ and concentrations of $\mathrm{Sm}$ and Nd were measured on a RPQ Finnigan MAT 262 multi-collector mass spectrometer in static mode. The precision of Sm and Nd contents and ${ }^{147} \mathrm{Sm} /{ }^{144} \mathrm{Nd}$ ratios was ca. $0.5 \%$ (28) and ca. $0.005 \%$ (28) for ${ }^{143} \mathrm{Nd} /{ }^{144} \mathrm{Nd}$ ratios. All ${ }^{147} \mathrm{Sm} /{ }^{144} \mathrm{Nd}$ and ${ }^{143} \mathrm{Nd} /{ }^{144} \mathrm{Nd}$ ratios were normalised to the standard value of ${ }^{146} \mathrm{Nd} /{ }^{144} \mathrm{Nd}=0.7219$, and adjusted to ${ }^{143} \mathrm{Nd} /{ }^{144} \mathrm{Nd}=0.521100$ (JNd-1standard). The mean ${ }^{143} \mathrm{Nd} /{ }^{144} \mathrm{Nd}$ ratio for the JNd-1standard was $0.512094 \pm 0.000002(2 \delta, \mathrm{n}=20)$ during the study. The $\varepsilon \mathrm{Nd}(\mathrm{t})$ values and $\mathrm{T}_{\mathrm{Nd}}(\mathrm{DM})$ mean crustal residence ages were calculated using currently accepted parameters of CHUR [32]: ${ }^{143} \mathrm{Nd} /{ }^{144} \mathrm{Nd}=0.512638$ and ${ }^{147} \mathrm{Sm} /{ }^{144} \mathrm{Nd}=0.1967$ and DM [33]: ${ }^{143} \mathrm{Nd} /{ }^{144} \mathrm{Nd}=0.513151$ and ${ }^{147} \mathrm{Sm} /{ }^{144} \mathrm{Nd}=0.2136$.

\section{Results}

\subsection{Geochemistry}

The Listvyanka and Goloustnaya dolerites are geochemically similar to subalkaline basalt according to LeBas et al. [34] (Figure 5a). Silica compositions of the studied samples are between 46.7 and $50.4 \mathrm{wt} . \%$ and the sum of $\mathrm{Na}_{2} \mathrm{O}$ and $\mathrm{K}_{2} \mathrm{O}$ varies from 2.2 to $3.9 \mathrm{wt} . \%$. On the Jensen [35] diagram, all dolerites fall in the field of high-Fe tholeiite (Figure $5 \mathrm{~b}$ ).

All the analyzed rocks are characterized by lower to moderate mg\#, ranging from 48 to 54 in the Listvyanka dolerites and from 36 to 50 in the Goloustnaya dolerites (Table 1, Figure 6). The dolerites have high contents of $\mathrm{TiO}_{2}(1.6-2.6 \mathrm{wt} . \%$ and 2.0-3.3 wt.\% in Listvyanka and Goloustnaya dolerites, respectively) and $\mathrm{P}_{2} \mathrm{O}_{5}(0.19-0.31 \mathrm{wt} . \%$ and $0.24-0.74 \mathrm{wt} . \%$, respectively) (Table 1, Figure 6). All dolerites demonstrate negative correlations between mg\# and $\mathrm{TiO}_{2}, \mathrm{P}_{2} \mathrm{O}_{5}, \mathrm{La}$, Th, $\mathrm{Zr}$, and $\mathrm{Y}$ (Figure 6).

Primitive mantle-normalized [36] diagrams (Figure 7a) show that the Listvyanka dolerites are characterized by positive $\mathrm{Nb}$-Ta, $\mathrm{P}$ and Ti anomalies, a slightly negative $\mathrm{Sr}$ anomaly, and variations in the LILE ( $\mathrm{Rb}, \mathrm{Ba}$, and $\mathrm{K}$ ). Similar diagrams (Figure $\mathrm{7b}$ ) for the Goloustnaya dolerites demonstrate no $\mathrm{Nb}$-Ta and $\mathrm{Ti}$ anomalies and negative $\mathrm{Sr}$ anomaly. We conclude that the trace element patterns of 
Listvyanka and Goloustnaya dolerites are most similar to basalts of the oceanic island basalts (OIB) type (Figure $7 \mathrm{a}, \mathrm{b})$.

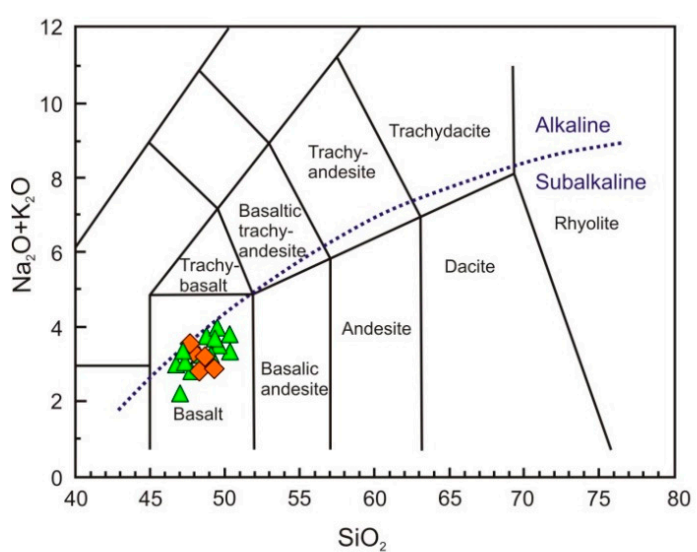

(a)

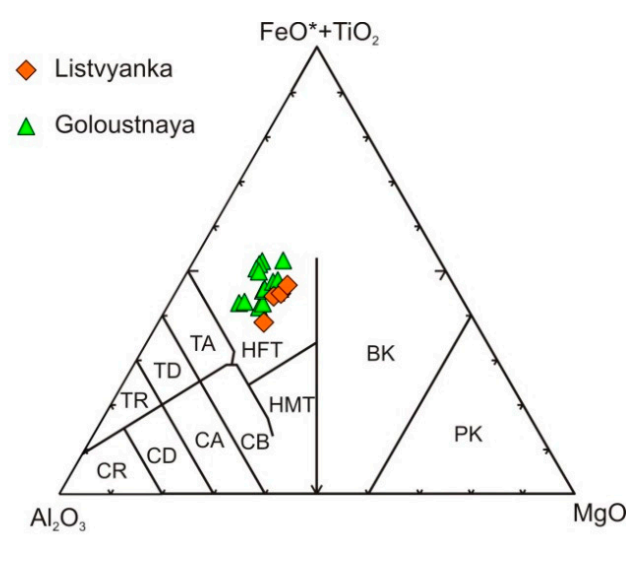

(b)

Figure 5. $\left(\mathrm{Na}_{2} \mathrm{O}+\mathrm{K}_{2} \mathrm{O}\right)-\mathrm{SiO}_{2}$ diagram of LeBas et al. [34] (a); $\mathrm{MgO}-\left(\mathrm{FeO} *+\mathrm{TiO}_{2}\right)-\mathrm{Al}_{2} \mathrm{O}_{3}$ diagram of Jensen [35] (b) for Listvyanka and Goloustnaya dolerites.
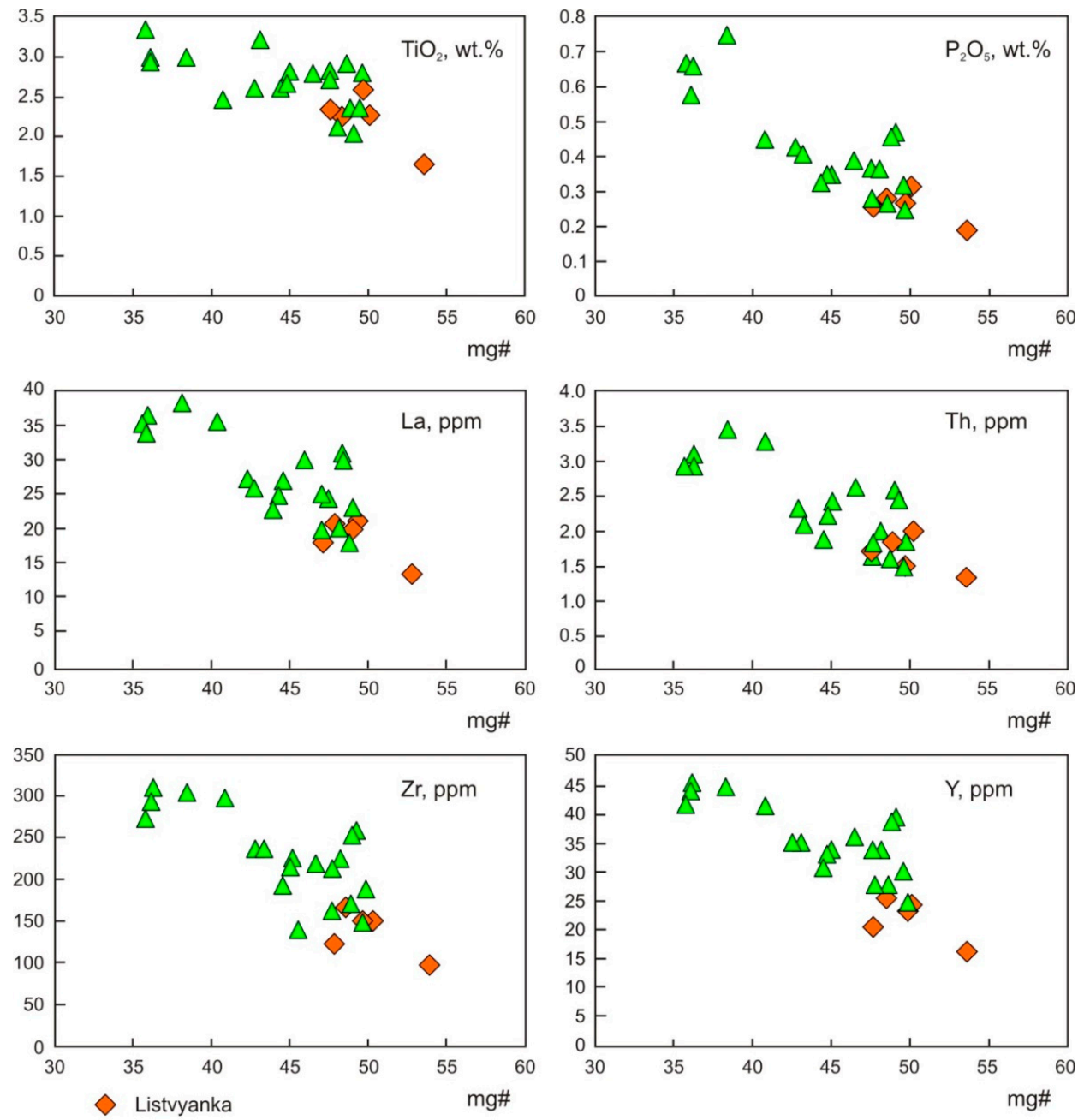

$\triangle$ Goloustnaya

Figure 6. Variation of $\mathrm{TiO}_{2}, \mathrm{P}_{2} \mathrm{O}_{5}, \mathrm{La}, \mathrm{Th}, \mathrm{Zr}$ and $\mathrm{Y}$ with magnesium number, mg\# for Listvyanka and Goloustnaya dolerites. 

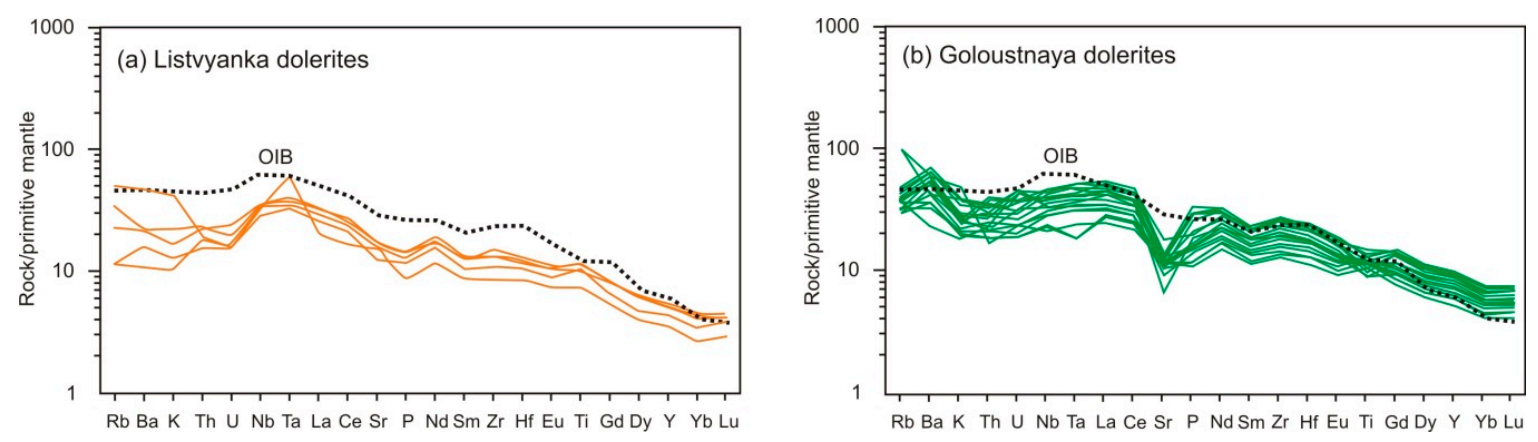

Figure 7. Primitive mantle-normalized [36] multi-element diagrams for Listvyanka (a) and Goloustnaya (b) dolerites. The OIB pattern is after Sun and McDonough [36].

All analyzed samples are enriched in REE. Chondrite-normalized [37] REE patterns of Listvyanka and Goloustnaya dolerites show a similar slight REE fractionation with $(\mathrm{La} / \mathrm{Yb})_{\mathrm{n}}=5.3-6.7$ and no Eu anomalies $\left(\mathrm{Eu} / \mathrm{Eu}^{*}=0.92-1.10\right)$ (Figure $\left.8 \mathrm{a}, \mathrm{b}\right)$.
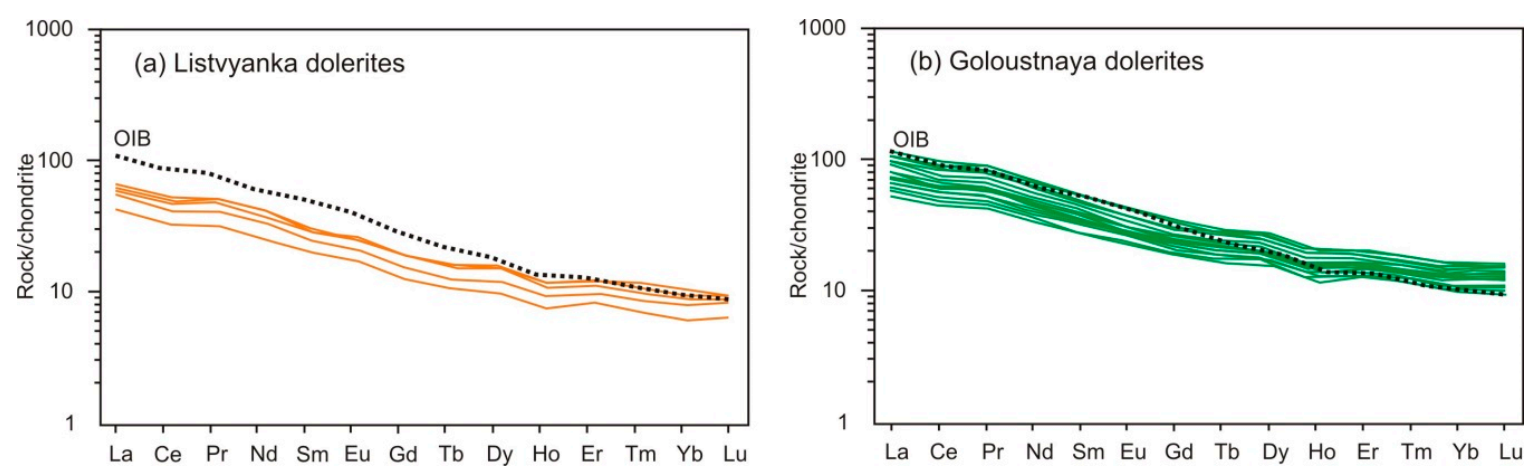

Figure 8. Chondrite-normalized [37] REE patterns for Listvyanka (a) and Goloustnaya (b) dolerites. The oceanic island basalts (OIB) pattern is after Sun and McDonough [36].

\subsection{Nd Isotope Systematics}

The Sm-Nd isotopic composition was analyzed in three Listvyanka dolerites and five Goloustnaya dolerites (Table 2, Figure 9). The Listvyanka dolerites are characterized by a slightly positive $\varepsilon N d(t)$ values range from +1.1 to +1.5 . The $\varepsilon N d(t)$ values for Goloustnaya dolerites are slightly negative and close to zero varying from -0.9 to +0.1 . The narrow $\varepsilon \mathrm{Nd}(\mathrm{t})$ range in Listvyanka and Goloustnaya dolerites is apparently consistent with their origin from a relatively homogeneous source. Moreover, $\varepsilon \mathrm{Nd}(\mathrm{t})$ values in analyzed samples do not correlate with their $\mathrm{SiO}_{2}$ contents (Figure 9).

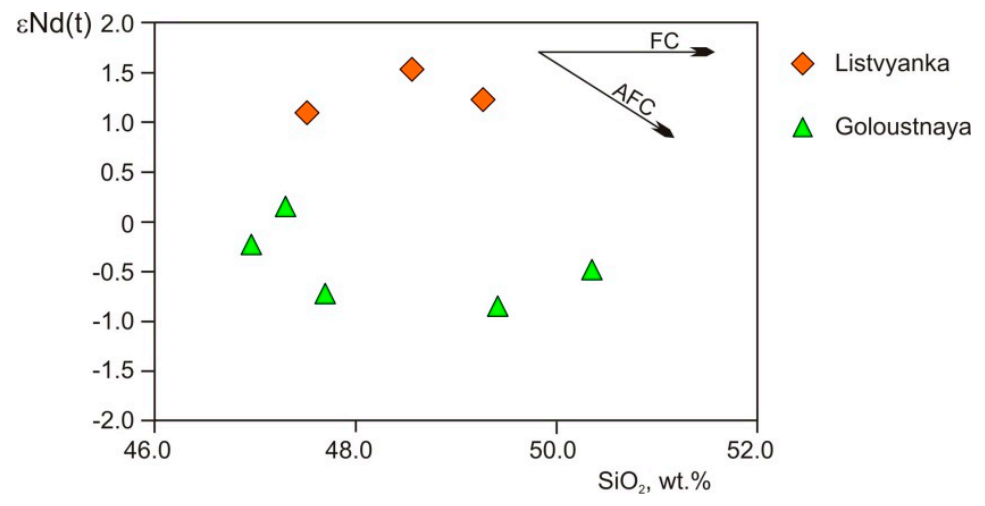

Figure 9. $\varepsilon \mathrm{Nd}(\mathrm{t})-\mathrm{SiO}_{2}$ diagram for Listvyanka and Goloustnaya dolerites. $\mathrm{FC}$, fractional crystallization; AFC, assimilation and fractional crystallization. 


\section{Discussion}

\subsection{Petrogenesis of Dolerites}

The high contents of $\mathrm{FeO}^{*}, \mathrm{TiO}_{2}, \mathrm{P}_{2} \mathrm{O}_{5}, \mathrm{HFSE}$ (Table 1, Figure 6), primitive mantle-normalized diagrams spidergrams (Figure 7a,b) and chondrite-normalized REE patterns (Figure 8a,b) indicate that the Listvyanka and Goloustnaya dolerites are geochemically close to OIB. All studied dolerites plot near the OIB field in the $\mathrm{Zr} / \mathrm{Nb}-\mathrm{Nb} / \mathrm{Th}$ and $\mathrm{Nb} / \mathrm{Y}-\mathrm{Zr} / \mathrm{Y}$ diagrams of Condie [38], suggesting that the parent magma originated from a plume-related source (Figure 10a,b).

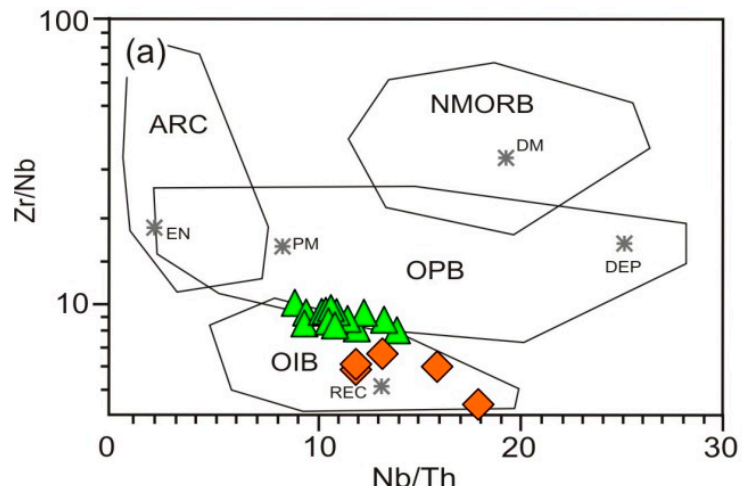

Listvyanka

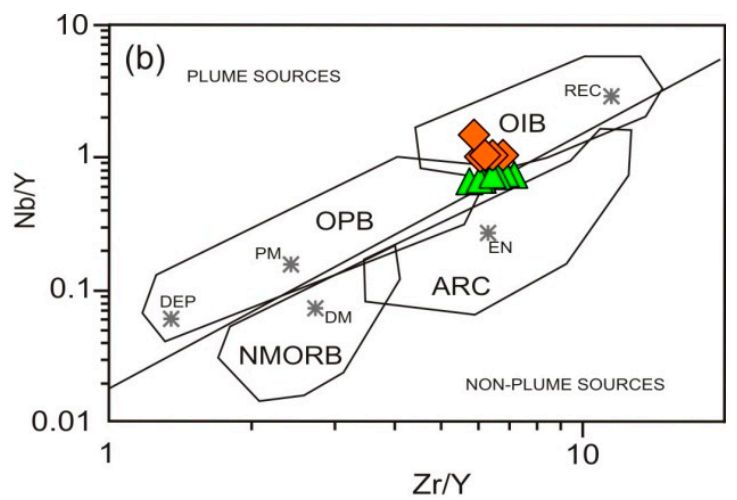

$\triangle$ Goloustnaya

Figure 10. $\mathrm{Zr} / \mathrm{Nb}-\mathrm{Nb} / \mathrm{Th}$ (a) and $\mathrm{Nb} / \mathrm{Y}-\mathrm{Zr} / \mathrm{Y}$ (b) diagrams [38] for Listvyanka and Goloustnaya dolerites. Abbreviations: ARC, arc-related basalts; NMORB, normal mid-ocean ridge basalts; OIB, oceanic island basalts; OPB, oceanic plateau basalts. DM, shallow depleted mantle; PM, primitive mantle; DEP, deep depleted mantle; REC, recycled component; EN, enriched component.

At the same time, the Listvyanka and Goloustnaya dolerites vary in incompatible element ratios, including $\mathrm{Nb} / \mathrm{Y}, \mathrm{Zr} / \mathrm{Nb}, \mathrm{Nb} / \mathrm{Yb}$, which reflect the sources and evolution of mafic melts, because they are invariants during fractional differentiation. All studied Listvyanka and Goloustnaya samples plot in the mid-ocean ridge basalts (MORB)-OIB array in the $\mathrm{Th} / \mathrm{Yb}-\mathrm{Nb} / \mathrm{Yb}$ diagram of Pearce [39], forming non-overlapping fields (Figure 11a). There are no points above the MORB-OIB array, suggesting the absence of crustal input in mantle sources of all studied dolerites. In the $\mathrm{TiO}_{2} / \mathrm{Yb}-\mathrm{Nb} / \mathrm{Yb}$ diagram of Pearce [39], the Goloustnaya dolerites plot in the tholeiitic OIB field while the Listvyanka dolerites lies near the tholeiitic/alkalic line (Figure 10b). We admit some differences in Listvyanka and Goloustnaya dolerite sources. The geochemical affinities of the Listvyanka dolerites (Figure 7a, Figure 10a,b and Figure 11a,b) as well as their slightly positive $\varepsilon N d(t)$ values (Figure 9) allow us to assume a mantle plume-related source. As for the Goloustnaya dolerites, their slightly negative $\varepsilon \mathrm{Nd}(\mathrm{t})$ value (Figure 9), absence of expressed positive $\mathrm{Nb}$-Ta and $\mathrm{Ti}$ anomalies in spidergrams (Figure $7 \mathrm{~b}$ ), and location in the tholeiitic OIB field in the $\mathrm{TiO}_{2} / \mathrm{Yb}-\mathrm{Nb} / \mathrm{Yb}$ diagram (Figure 11b) suggest a possible incorporation of a minor lithospheric component to the mantle plume-related source. Moreover, the increase in $\mathrm{Zr} / \mathrm{Nb}$ and $\mathrm{Nb} / \mathrm{Y}$ ratios from Listvyanka to Goloustnaya dolerites (Figure 10) could be related also to an increasing degree of melting in the mantle source. 

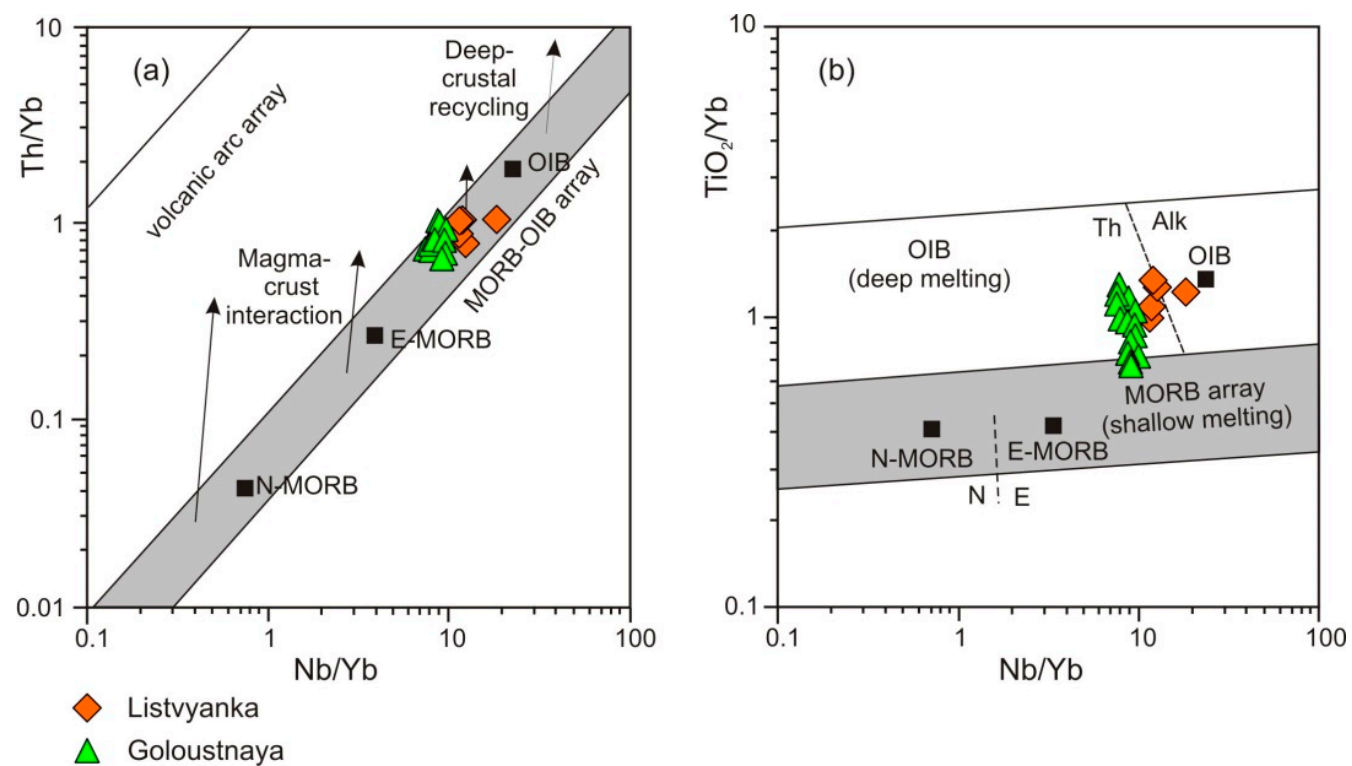

Figure 11. $\mathrm{Th} / \mathrm{Yb}-\mathrm{Nb} / \mathrm{Yb}(\mathbf{a})$ and $\mathrm{TiO}_{2} / \mathrm{Yb}-\mathrm{Nb} / \mathrm{Yb}(\mathbf{b})$ diagrams [39] for Listvyanka and Goloustnaya dolerites. Abbreviations: N-MORB, normal mid-ocean ridge basalts; E-MORB, enriched mid-ocean ridge basalts; OIB, oceanic island basalts; Th, tholeiitic OIB; Alk, alkalic OIB.

On the $\mathrm{Zr} / \mathrm{Y}-\mathrm{Zr}$ diagram of Pearce and Norry [40] and $\mathrm{Zr} / 4-\mathrm{Nb}^{*} 2-\mathrm{Y}$ diagram of Meschede [41], all dolerites fall in the fields of within-plate basalts (WPB) (Figure 12a,b), indicating their formation in an intracontinental extensional setting. We assume that this extension could have been caused by a rising mantle plume. In the $\mathrm{Zr} / 4-\mathrm{Nb}^{*} 2-\mathrm{Y}$ diagram of Meschede [41] (Figure 12b), both the Listvyanka and Goloustnaya dykes occur in a combined alkali basalt-tholeiite field, but with the Listvyanka dykes plotting closer to the alkaline field (Figure 12b), similar to the pattern in the $\mathrm{TiO}_{2} / \mathrm{Yb}-\mathrm{Nb} / \mathrm{Yb}$ diagram of Pearce [39] (Figure 11b).
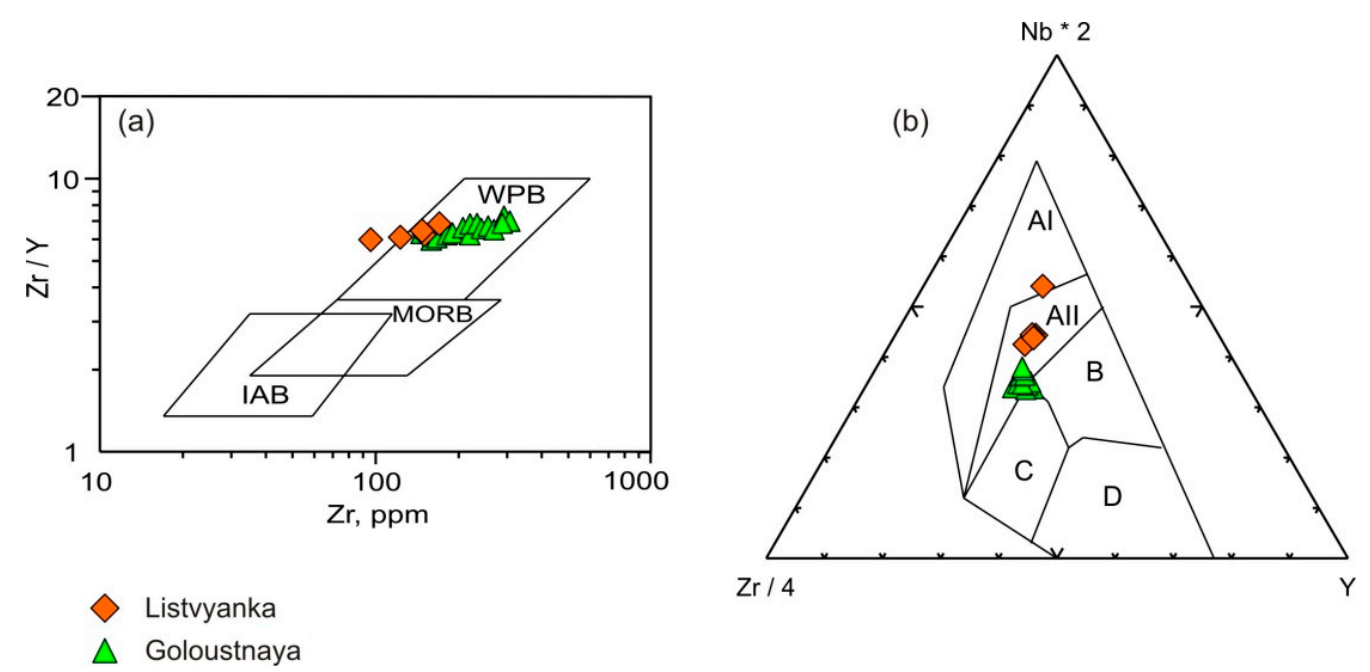

Figure 12. $\mathrm{Zr} / \mathrm{Y}-\mathrm{Zr}$ diagram of Pearce and Norry [40] (a); $\mathrm{Zr} / 4-\mathrm{Nb}^{*} 2-\mathrm{Y}$ diagram of Meschede [41] (b) for Listvyanka and Goloustnaya dolerites. Abbreviations: (a): IAB, island-arc basalts; MORB, mid-ocean ridge basalts; WPB, within-plate basalts; (b): AI, within-plate alkali basalts; AII, within-plate alkali basalts and within-plate tholeiites; B, E-MORB; C, within-plate tholeiites and volcanic-arc basalts; D, N-MORB and volcanic-arc basalts. 
As we mentioned before, the Listvyanka dolerites are a bit older than the Goloustnaya dolerites (1350 $\pm 6 \mathrm{Ma}$ and $1338 \pm 3 \mathrm{Ma}$, respectively). We assume that some differences in the chemical compositions of the Listvyanka and Goloustnaya dolerites could be related to an increasing extension triggered by a rising mantle plume and some thinning of the lithosphere, which causes some change in melting conditions. These differences may also reflect a possible input of lithospheric component to the mantle plume-related source of the Goloustnaya dolerites.

\subsection{Geodynamic Setting}

Geochemical and isotopic affinities of the Listvyanka and Goloustnaya dolerites suggest their generation due to a rising mantle plume in the continental lithosphere of the Siberian craton. As mentioned before, the southern part of the Siberian craton was located in close proximity to the northern part of Laurentia in the Mesoproterozoic. These cratons formed the core of Proterozoic supercontinents of Columbia/Nuna and Rodinia [2,5-7], etc. Ernst et al. [7] show that the $1350 \pm 6 \mathrm{Ma}$ Listvyanka dolerites of southern Siberia are synchronous with the $1353 \pm 2$ Ma Barking Dog gabbro sill from the Wellington Inlier of Victoria Island in northern Canada. Moreover, an Sm-Nd imprecise age of $1339 \pm 54$ Ma was obtained for one dyke in the Sette Daban area of south-eastern Siberia [42]. Thus, two pulses of dolerite magmatism occurred in the southern part of the Siberian craton and in northern Laurentia at ca. 1353 and $1338 \mathrm{Ma}$. The relatively small age difference (15 million years) between these two pulses suggests that they could be related to the same magmatic event. Geochemical and isotopic data of the Listvyanka and Goloustnaya dolerites suggest that they are related to the same mantle plume, but the more primitive and younger Goloustnaya dolerites could be intruded upon during increasing extension.

The Listvyanka and Goloustnaya dolerites provide the first documented signatures of Mesoproterozoic mafic magmatic activity near the southern margin of the Siberian craton. Slightly older (1381 $\pm 22 \mathrm{Ma})$ rift-related anorogenic granitoids were found along the western margin of the Siberian craton (Yenisey Ridge) [43,44]. With uncertainty, this age could also match with the $1385 \mathrm{Ma}$ Chieress LIP of northern Siberia (see below). Older Mesoproterozoic magmatic events related to mantle plumes are widely distributed in the northern part of the Siberian craton (Anabar shield, Olenek uplift, Udzha aulacogen): (i) the dolerite dykes with an ages of Sm-Nd $1513 \pm 51 \mathrm{Ma}$ [45] and U-Pb $1503 \pm 5 \mathrm{Ma}$ [46], as well as the U-Pb $1473 \pm 24 \mathrm{Ma}$ intrusions within the Olenek uplift [15] all belonging to the 1501 Ma Kuonmaka LIP [47]; and (ii) the U-Pb $1384 \pm 2$ Ma dyke [46] in the Anabar shield, U-Pb $1386 \pm 30$ Ma dykes in the Udzha aulakogen [48], and the Severobyrrang sills of the Taimyr peninsula [49] all belonging to the 1385 Ma Chieress LIP. These events do not have coeval analogues in northern Laurentia [47]. Therefore, there are two separate mantle plumes, which apparently were located directly under the northern part of the Siberian craton at ca. 1501 and 1385 Ma. Coeval magmatic events are recorded not only in the north of the Siberian craton, but also in the Baltica, Congo and San Francisco cratons (see reviews in [18,50-52]). This supports an assumption that Early Mesoproterozoic mafic magmatism might be related to the mantle plume activities within the closely located margins of these ancient cratons in accordance with published paleogeographic reconstructions $[19,50,52]$.

New data show that the focus of early to middle Mesoproterozoic magmatic activity in Siberia migrated from north to south and the ca. 1350 Ma mantle plume was located under the southern part of the Siberian craton and northern Laurentia.

\section{Conclusions}

1. The 1.35 Ga Listvyanka and 1.34 Ga Goloustnaya dolerite dykes form two Middle Mesoproterozoic swarms in Irkutsk Promontory of the southern part of the Siberian craton. The Listvyanka dykes are sub-vertical with a NNE trend, while the Goloustnaya dykes are characterized by a prevailing $\mathrm{W}$ trend. 
2. The Listvyanka and Goloustnaya dolerites in their chemical composition correspond to sub-alkaline tholeiitic basalts with lower to moderate mg\#, varying from 36 to 54 . The trace and rare earth element abundances in these dolerites are generally close to basalts of the OIB type. The Listvyanka dolerites demonstrate slightly positive $\varepsilon \mathrm{Nd}(\mathrm{t})$ values $(+1.1$ to +1.5$)$, while the Goloustnaya dolerites are characterized by lower $\varepsilon \mathrm{Nd}(\mathrm{t})$ values varying from -0.9 to +0.1 .

3. Geochemical and isotopic affinities of the Listvyanka dolerites suggest their enrichment by a mantle plume-related source. Based on geochemical and isotopic data of the Goloustnaya dolerites, we assume some input of a lithospheric component to their mantle plume-related source.

4. The emplacement of the Listvyanka and Goloustnaya dolerites took place in an intracontinental extensional setting, caused by a rising mantle plume.

5. Listvyanka and Goloustnaya dolerites are synchronous with several mafic magmatic events in northern Laurentia and likely represent part of the Mesoproterozoic plumbing system of a Siberian-Laurentian LIP.

Author Contributions: T.V.D. collected samples, interpreted the data, prepared tables and figures, wrote the manuscript; D.P.G. collected samples, helped in the interpretation of data and in writing the manuscript; R.E.E. prepared some figures, helped with the part of the manuscript related to Geodynamic Setting and also reviewed in detail the final version of the manuscript; S.A.P. helped with the preparation of the Introduction and Geodynamic Setting sections; A.M.M. made structural studies and helped with writing the Geological Setting section; E.I.D. performed the $\mathrm{Nd}$ isotope study.

Funding: This research was supported by grant 18-17-00101 from the Russian Science Foundation. R.E. Ernst was partially supported from Mega-Grant 14.Y26.31.0012 of the government of the Russian Federation.

Acknowledgments: This is a contribution to IGCP 648 (http:/ / geodynamics.curtin.edu.au/igcp-648/).

Conflicts of Interest: The authors declare no conflicts of interest.

\section{References}

1. Gladkochub, D.P.; Sklyarov, E.V.; Donskaya, T.V.; Stanevich, A.M.; Mazukabzov, A.M. A period of global uncertainty (Blank Spot) in the Precambrian history of the southern Siberian Craton and the problem of the transproterozoic supercontinent. Dokl. Earth Sci. 2008, 421, 774-778. [CrossRef]

2. Gladkochub, D.P.; Donskaya, T.V.; Wingate, M.T.D.; Mazukabzov, A.M.; Pisarevsky, S.A.; Sklyarov, E.V.; Stanevich, A.M. A one-billion-year gap in the Precambrian history of the southern Siberian craton and the problem of the Transproterozoic supercontinent. Am. J. Sci. 2010, 310, 812-825. [CrossRef]

3. Roberts, N.M.W. The boring billion? Lid tectonics, continental growth and environmental change associated with the Columbia supercontinent. Geosci. Front. 2013, 4, 681-691. [CrossRef]

4. Cawood, P.A.; Hawkesworth, C.J. Earth's middle age. Geology 2014, 42, 503-506. [CrossRef]

5. Zhang, S.; Li, Z.X.; Evans, D.A.D.; Wu, H.; Li, H.; Dong, J. Pre-Rodinia supercontinent Nuna shaping up: A global synthesis with new paleomagnetic results from North China. Earth Planet. Sci. Lett. 2012, 353-354, $145-155$. [CrossRef]

6. Cawood, P.A.; Strachan, R.; Pisarevsky, S.A.; Gladkochub, D.P.; Murphy, J.B. Linking collisional and accretionary orogens during Rodinia assembly and breakup: Implications for models of supercontinent cycles. Earth Planet. Sci. Lett. 2016, 449, 118-126. [CrossRef]

7. Ernst, R.E.; Hamilton, M.A.; Söderlund, U.; Hanes, J.A.; Gladkochub, D.P.; Okrugin, A.V.; Kolotilina, T.; Mekhonoshin, A.S.; Bleeker, W.; LeCheminant, A.N.; et al. Long-lived connection between southern Siberia and northern Laurentia in the Proterozoic. Nat. Geosci. 2016, 9, 464-469. [CrossRef]

8. Sears, J.W.; Price, R.A. The Siberian connection: A case for the Pre-cambrian separation of the North American and Siberian cratons. Geology 1978, 6, 267-270. [CrossRef]

9. Sears, J.W.; Price, R.A. New look at the Siberian connection: No SWEAT. Geology 2000, 28, 423-426. [CrossRef]

10. Sears, J.W.; Price, R.A. Tightening the Siberian connection to western Laurentia. Geol. Soc. Am. Bull. 2003, 115, 943-953. [CrossRef]

11. Hoffman, P.F. Did the breakout of Laurentia turn Gondwanaland inside out? Science 1991, 252, 1409-1412. [CrossRef] [PubMed]

12. Condie, K.C.; Rosen, O.M. Laurentia-Siberia connection revisited. Geology 1994, 22, 168-170. [CrossRef] 
13. Pisarevsky, S.A.; Natapov, L.M. Siberia and Rodinia. Tectonophysics 2003, 375, 221-245. [CrossRef]

14. Li, Z.X.; Bogdanova, S.V.; Collins, A.; Davidson, A.; De Waele, B.; Ernst, R.E.; Fitzsimons, I.; Fuck, R.; Gladkochub, D.; Jacobs, J.; et al. Assembly, configuration, and break-up history of Rodinia: A synthesis. Precambrian Res. 2008, 160, 179-210. [CrossRef]

15. Wingate, M.T.D.; Pisarevsky, S.A.; Gladkochub, D.P.; Donskaya, T.V.; Konstantinov, K.M.; Mazukabzov, A.M.; Stanevich, A.M. Geochronology and paleomagnetism of mafic igneous rocks in the Olenek Uplift, northern Siberia: Implications for Mesoproterozoic supercontinents and paleogeography. Precambrian Res. 2009, 170, 256-266. [CrossRef]

16. Evans, D.A.D.; Mitchell, R.N. Assembly and breakup of the core of Paleoproterozoic-Mesoproterozoic supercontinent Nuna. Geology 2011, 39, 443-446. [CrossRef]

17. Evans, D.A.D.; Veselovsky, R.V.; Petrov, P.Y.; Shatsillo, A.V.; Pavlov, V.E. Paleomagnetism of Mesoproterozoic margins of the Anabar Shield: A hypothesized billion-year partnership of Siberia and northern Laurentia. Precambrian Res. 2016, 281, 639-655. [CrossRef]

18. Gladkochub, D.P.; Pisarevsky, S.A.; Donskaya, T.V.; Ernst, R.E.; Wingate, M.T.D.; Söderlund, U.; Mazukabzov, A.M.; Sklyarov, E.V.; Hamilton, M.A.; Hanes, J.A. Proterozoic mafic magmatism in Siberian craton: An overview and implications for paleocontinental reconstruction. Precambrian Res. 2010, 183, 660-668. [CrossRef]

19. Pisarevsky, S.A.; Elming, S.-Å.; Pesonen, L.J.; Li, Z.X. Mesoproterozoic paleogeography: Supercontinent and beyond. Precambrian Res. 2014, 244, 207-225. [CrossRef]

20. Pourteau, A.; Smit, M.A.; Li, Z.X.; Collins, W.J.; Nordsvan, A.R.; Volante, S.; Li, J. 1.6 Ga crustal thickening along the final Nuna suture. Geology 2018, 46, 959-962. [CrossRef]

21. Goodge, J.W.; Vervoort, J.D.; Fanning, C.M.; Brecke, D.M.; Farmer, G.L.; Williams, I.S.; Myrow, P.M.; DePaolo, D.J. A positive test of East Antarctica-Laurentia juxtaposition within the Rodinia supercontinent. Science 2008, 321, 235-240. [CrossRef] [PubMed]

22. Betts, P.G.; Giles, D.; Schaefer, B.F. Comparing 1800-1600 Ma accretionary and basin processes in Australia and Laurentia: Possible geographic connections in Columbia. Precambrian Res. 2008, 166, 81-92. [CrossRef]

23. Rogers, C.; Kamo, S.L.; Söderlund, U.; Hamilton, M.A.; Ernst, R.E.; Cousens, B.; Harlan, S.S.; Wade, C.E.; Thorkelson, D.J. Geochemistry and U-Pb geochronology of 1590 and 1550 Ma mafic dyke swarms of Western Laurentia: Mantle plume magmatism shared with Australia. Lithos 2018, 314-315, 216-235. [CrossRef]

24. Rogers, J.J.W.; Santosh, M. Tectonics and surface effects of the supercontinent Columbia. Gondwana Res. 2009, 15, 373-380. [CrossRef]

25. Gladkochub, D.P.; Donskaya, T.V.; Ernst, R.E.; Hamilton, M.A.; Mazukabzov, A.M.; Pisarevsky, S.A.; Kamo, S. New Ectasian event of basic magmatism in the Southern Siberian craton. Dokl. Earth Sci. 2018, in press.

26. Rosen, O.M.; Condie, K.C.; Natapov, L.M.; Nozhkin, A.D. Archean and Early Proterozoic evolution of the Siberian Craton: A preliminary assessment. In Archean Crustal Evolution; Condie, K.C., Ed.; Elsevier: Amsterdam, The Netherlands, 1994; pp. 411-459. ISBN 0444816216, 978-0444816214.

27. Rosen, O.M. The Siberian craton: Tectonic zonation and stages of evolution. Geotectonics 2003, 37, $175-192$.

28. Gladkochub, D.; Pisarevsky, S.A.; Donskaya, T.; Natapov, L.M.; Mazukabzov, A.; Stanevich, A.M.; Slkyarov, E. Siberian Craton and its evolution in terms of Rodinia hypothesis. Episodes 2006, 29, 169-174.

29. Pisarevsky, S.A.; Natapov, L.M.; Donskaya, T.V.; Gladkochub, D.P.; Vernikovsky, V.A. Proterozoic Siberia: A promontory of Rodinia. Precambrian Res. 2008, 160, 66-76. [CrossRef]

30. Panteeva, S.V.; Gladkochoub, D.P.; Donskaya, T.V.; Markova, V.V.; Sandimirova, G.P. Determination of 24 trace elements in felsic rocks by inductively coupled plasma mass spectrometry after lithium metaborate fusion. Spectrochim. Acta Part B At. Spectrosc. 2003, 58, 341-350. [CrossRef]

31. Vanin, V.A.; Chugaev, A.V.; Demonterova, E.I.; Gladkochub, D.P.; Mazukabzov, A.M. Geologic structure of the Mukodek gold field (northern Transbaikalia) and sources of matter (Pb-Pb and Sm-Nd data). Russ. Geol. Geophys. 2018, 59, 1078-1086. [CrossRef]

32. Jacobsen, S.B.; Wasserburg, G.J. Sm-Nd isotopic evolution of chondrites and achondrites, II. Earth Planet. Sci. Lett. 1984, 67, 137-150. [CrossRef]

33. Goldstein, S.J.; Jacobsen, S.B. Nd and Sr isotopic systematics of rivers water suspended material: Implications for crustal evolution. Earth Planet. Sci. Lett. 1988, 87, 249-265. [CrossRef]

34. LeBas, M.J.; LeMaitre, R.W.; Streckeisen, A.; Zanettin, B. A chemical classification of volcanic-rocks based on the total alkali silica diagram. J. Petrol. 1986, 27, 745-750. [CrossRef] 
35. Jensen, L.S. A New Cation Plot for Classifying Subalkalic Volcanic Rocks; Ontario Division of Mines, Miscellaneous Paper: Toronto, ON, Canada, 1976; p. 22.

36. Sun, S.; McDonough, W.F. Chemical and isotopic systematics of oceanic basalts: Implications for mantle composition and processes Basins. In Magmatism in the Ocean Basins; Saunders, A.D., Norry, M.J., Eds.; Special Publications 42; Geological Society of London: London, UK, 1989; pp. 313-345. ISBN 1897799128, 978-1897799123.

37. Wakita, H.; Schmitt, R.A.; Rey, P. Elemental abundances of major, minor, and trace elements in Apollo 11 lunar rocks, soil and core samples. In Proceedings of the Apollo 11 Lunar Science Conference, Houston, TX, USA, 5-8 January 1970. Geochim. Cosmochim. Acta 1970, 34 (Suppl. 1), 1685-1717.

38. Condie, K.C. High field strength element ratios in Archean basalts: A window to evolving sources of mantle plumes? Lithos 2005, 79, 491-504. [CrossRef]

39. Pearce, J.A. Geochemical fingerprinting of oceanic basalts with applications to ophiolite classification and the search for Archean oceanic crust. Lithos 2008, 100, 14-48. [CrossRef]

40. Pearce, J.A.; Norry, M.J. Petrogenetic implications of Ti, Zr, Y, and $\mathrm{Nb}$ variations in volcanic rocks. Contrib. Mineral. Petrol. 1979, 69, 33-47. [CrossRef]

41. Meschede, M. A method of discriminating between different types of mid-ocean ridge basalts and continental tholeiites with the Nb-Zr-Y diagram. Chem. Geol. 1986, 56, 207-218. [CrossRef]

42. Khudoley, A.K.; Kropachev, A.P.; Tkachenko, V.I.; Rublev, A.G.; Sergeev, S.A.; Matukov, D.I.; Lyahnitskaya, O.Y. Mesoproterozoic to Neoproterozoic evolution of the Siberian craton and adjacent microcontinents: An overview with constraints for a Laurentian connection. Soc. Sediment. Geol. Spéc. Publ. 2007, 86, 209-226. [CrossRef]

43. Popov, N.V.; Likhanov, I.I.; Nozhkin, A.D. Mesoproterozoic granitoid magmatism in the Trans-Angara Segment of the Yenisei Range: U-Pb evidence. Dokl. Earth Sci. 2010, 431, 418-423. [CrossRef]

44. Likhanov, I.I.; Popov, N.V.; Nozhkin, A.D. The oldest granitoids in the Transangarian part of the Yenisey Ridge: $\mathrm{U}-\mathrm{Pb}$ and $\mathrm{Sm}-\mathrm{Nd}$ data and geodynamic settings. Geochem. Int. 2012, 50, 869-877. [CrossRef]

45. Veselovskiy, R.V.; Petrov, P.Y.; Karpenko, S.F.; Kostitsyn, Y.A.; Pavlov, V.E. New paleomagnetic and isotopic data on the Mesoproterozoic igneous complex on the northern slope of the Anabar massif. Dokl. Earth Sci. 2006, 411, 1190-1194. [CrossRef]

46. Ernst, R.E.; Buchan, K.L.; Hamilton, M.A.; Okrugin, A.V.; Tomshin, M.D. Integrated paleomagnetism and $\mathrm{U}-\mathrm{Pb}$ geochronology of mafic dikes of the eastern Anabar Shield region, Siberia: Implications for Mesoproterozoic paleolatitude of Siberia and comparison with Laurentia. J. Geol. 2000, 108, 381-401. [CrossRef] [PubMed]

47. Ernst, R.E.; Okrugin, A.V.; Veselovskiy, R.V.; Kamo, S.L.; Hamilton, M.A.; Pavlov, V.; Söderlund, U.; Chamberlain, K.R.; Rogers, C. The 1501 Ma Kuonamka Large Igneous Province of northern Siberia: U-Pb geochronology, geochemistry, and links with coeval magmatism on other crustal blocks. Russ. Geol. Geophys. 2016, 57, 653-671. [CrossRef]

48. Malyshev, S.V.; Pasenko, A.M.; Ivanov, A.V.; Gladkochub, D.P.; Savatenkov, V.M.; Meffre, S.; Abersteiner, A.; Kamenetsky, V.S. Geodynamic significance of the Mesoproterozoic magmatism of the Udzha paleo-rift (northern Siberian Craton) based on U-Pb geochronology and paleomagnetic data. Minerals 2018, in press.

49. Priyatkina, N.; Collins, W.J.; Khudoley, A.; Zastrozhnov, D.; Ershova, V.; Chamberlain, K.; Shatsillo, A.; Proskurnin, V. The Proterozoic evolution of northern Siberian Craton margin: A comparison of U-Pb-Hf signatures from sedimentary units of the Taimyr orogenic belt and the Siberian platform. Int. Geol. Rev. 2017, 59, 1632-1656. [CrossRef]

50. Gladkochub, D.P.; Donskaya, T.V.; Mazukabzov, A.M.; Pisarevsky, S.A.; Ernst, R.E.; Stanevich, A.M. The Mesoproterozoic mantle plume beneath the northern part of the Siberian craton. Russ. Geol. Geophys. 2016, 57, 671-685. [CrossRef] 
51. Ernst, R.E.; Wingate, M.T.D.; Buchan, K.L.; Li, Z.X. Global record of 1600-700 Ma large igneous provinces (LIPs): Implications for the reconstruction of the proposed Nuna (Columbia) and Rodinia supercontinents. Precambrian Res. 2008, 160, 159-178. [CrossRef]

52. Ernst, R.E.; Pereira, E.; Hamilton, M.A.; Pisarevsky, S.A.; Rodriques, J.; Tassinari, C.C.G.; Teixeira, W.; Van-Dunem, V. Mesoproterozoic intraplate magmatic 'barcode' record of the Angola portion of the Congo Craton: Newly dated magmatic events at 1505 and $1110 \mathrm{Ma}$ and implications for Nuna (Columbia) supercontinent reconstructions. Precambrian Res. 2013, 230, 103-118. [CrossRef]

(C) 2018 by the authors. Licensee MDPI, Basel, Switzerland. This article is an open access article distributed under the terms and conditions of the Creative Commons Attribution (CC BY) license (http:/ / creativecommons.org/licenses/by/4.0/). 